\title{
Effect of Cooking on Aluminium Migration to Meats Wrapped in Aluminium Foil Under Resturant Conditions
}

\author{
Khaled A. Osman ${ }^{1}$ and Hala H. Elsayed ${ }^{2}$
}

\begin{abstract}
Cooking of wrapped meats in aluminium foil is a common practice applied in many resturants, fast food outlets and hotels. However, there is concern araised recently regarding the toxicity of aluminium and its relations to some diseases (mainly chronic renal failure, various bone (osteomalacia) and neurological failures (Alzhemier's disease).

The effect of different cooking treatments $\left(150{ }^{\circ} \mathrm{C}\right.$ for $60 \mathrm{~min}, 200^{\circ} \mathrm{C}$ for $40 \mathrm{~min}$, and $250{ }^{\circ} \mathrm{C}$ for $20 \mathrm{~min}$ ) on aluminium (Al ) contents in red meats (beef, water buffalo, sheep) and white meats (chicken and turkey) cooked in aluminium foil were studied. Data revealed that cooking elevated Al concentrations of both red and white meats. The increase was $10.20-83.0 \%$ in red meats and 12.20$75 \%$ in poultry. The least increase was observed in the samples cooked at $150{ }^{\circ} \mathrm{C}$ for $60 \mathrm{~min}$, while the highest increase was traced in samples cooked at $250{ }^{\circ} \mathrm{C}$ for 20 min.

It can be concluded that the cooking processes affected the migration of $\mathrm{Al}$ and thereby cooked meats wrapped in aluminium foil may carry a risk to human health. Therefore,data of the present study can be a guide for resturants, fast food outlets and hotels to avoid wrapping of meats in aluminium foils prior to cooking, and use glass utensils for food cooking instead of aluminium foil in order to prevent contamination of meats with aluminium.In case of wrapping meats in aluminium foil, it is advisable to apply low cooking temperature for long time (i.e. $150{ }^{\circ} \mathrm{C}$ for $60 \mathrm{~min}$.). Data presented here indicated that such a treatment results in a decline of migration rate of $\mathrm{Al}$ from foil to food.
\end{abstract}

\section{INTRODUCTION}

Cooking of wrapped meats in aluminium foil is a common practice applied in many resturants, fast food outlets and hotels. Nowadayes, there is a significant concern about aluminium toxicity in patients with longstanding chronic renal failure (Meiri et al.,1993) and associated with various bone (osteomalacia) and neurological failures (Alzhemier's disease) (Gauthier et al., 2000; Rondeau et al., 2000; Grant et al, 2002; Polizzi et al., 2002; Miu et al., 2004; Gupta et al., 2005). Also, the consumption of foodstuffs with high levels of metals can cause gastric irritation and diarrhea

\footnotetext{
${ }^{1}$ Faculty of Agriculture, Alexandria University.

${ }^{2}$ High Institute of Tourism and Hotel Management and Restoration, Abou-Qeer, Alexandria.

Received November 6, 2007, Accepted December26, 2007
}

(WHO, 1982; Blunden and Wallace, 2003) and affect multiple organ systems.

Aluminium (Al) has a variety of industrial applications because of its attractive properties such as low specific gravity, high thermal and electric conductivity, attractive appearance, its corrosion resistance and easy processing properties (Ranau et al., 2001; Joshi et al., 2003). Aluminium is widely used for manufacturing household utensils and packaging materials. Aluminium foil is widely used for packaging, storing, and cooking of various foods. In addition, it is common practice to wrap meat and fish and cook them in the oven in order to prevent water uptake (McWilliams, 1989) and avoid direct heat (Ranau et al., 2001).

The extent of $\mathrm{Al}$ leaching into foods cooked in aluminium utensils or wrapped with aluminium foil was strongly related to several factors such as the type of aluminium utensils, $\mathrm{pH}$ of the food and/or cooking medium, form and composition of food, the old of utensils, duration of contact/cooking and presence of fluoride (Rajwanshi et al.,1999; Yaman et al., 2003, Scancar et al., 2004). In recent years, it is a common practice to wrap the meat to oven cooking and the possible relation between $\mathrm{Al}$ uptake and the potential effects of it, therefore the present study was conducted to detect the levels of $\mathrm{Al}$ content in different red meats (beef, water buffalo, sheep) and white meats (chicken and turkey) wrapped with aluminium foil and cooked in an oven at three different temperature/time periods (150 ${ }^{\circ} \mathrm{C}$ for $60 \mathrm{~min}, 200{ }^{\circ} \mathrm{C}$ for $40 \mathrm{~min}$, and $250{ }^{\circ} \mathrm{C}$ for 20 $\min )$.

\section{MATERIALS AND METHODS}

\section{Sampling and Cooking}

Fresh red meats of beef, water buffalo and sheep (muscles and livers) and white meats of chicken and turkey (breast and legs) were purchased from the local market in Alexandria. Egypt and immediately transferred to the laboratory. Samples from each species were trimmed to remove bones, skin and surface fat, cut into small pieces and then divided into portions. Samples (200 g for each) were wrapped in aluminium foil $(30 \times 30 \mathrm{~cm}$, thickness $12 \mathrm{~mm})$ and cooked under 
resturant conditions in an electrical oven $(1200 \mathrm{~W}, 220$ $\mathrm{V}, 50-60 \mathrm{~Hz})$ at $150{ }^{\circ} \mathrm{C}$ for $60 \mathrm{~min}, 200{ }^{\circ} \mathrm{C}$ for $40 \mathrm{~min}$ and $250{ }^{\circ} \mathrm{C}$ for $20 \mathrm{~min}$. At the same time, raw samples without cooking were analyzed for comparison. The raw and cooked samples were ground in a glass mortar to ensure homogeneity and subjected for metal analysis. Homogenized samples of each species were individually analyzed in triplicates.

\section{Sample Preparation for Aluminium Analysis}

Sample preparation was performed according to the method of NIOSH (1994) with slight modifications. In this method, $1 \mathrm{~g}$ of each sample was transferred to a beaker containing $10 \mathrm{ml}$ of digestion acid (nitric acid, sulfuric acid and perchloric acid in ratios of 3:1:1, respectively). The mixture was heated overnight at 110 ${ }^{\circ} \mathrm{C}$ and then at $250{ }^{\circ} \mathrm{C}$ until $1 \mathrm{ml}$ of mixture remained (2-3 hrs). The solution was left to cool and the contents of the beaker were transferred to a volumetric flask and diluted with $10 \%$ sulfuric acid to $5 \mathrm{ml}$. A blank was prepared in the same fashion. All reagents were of analytical-reagents grade and deionized water $(\mathrm{pH} 7.0)$ of $15 \mathrm{M} \Omega . \mathrm{cm}$ resistivity obtained from a water purification system (PURELAB Option-R, ELGA, UK) was used throughout the study.

\section{Determination}

Standard of $\mathrm{Al}$ metal solution $(1000 \mu \mathrm{g} / \mathrm{ml})$ was obtained from J. B. Baker Inc. (Phillipsburg, NJ, USA). Metal was measured by using atomic absorption spectrometer (AAS, Shimadzu Model AA-6200, Kyoto, Japan) at a wavelength of $309.3 \mathrm{~nm}$, equipped with a hollow cathode lamp, a $10 \mathrm{~cm}$ long slot-burner head and a nitrous oxide-acetylene flame. The operating conditions adjusted in the spectrometer were carried out according to the standard guidelines of the manufacture. Blank solution was prepared under identical conditions and the average signal was subtracted from analytical signals of samples. Working solutions were prepared directly from the metal standard solution $(1000 \mathrm{mg} / \mathrm{l})$ before determination. The solution concentration for $\mathrm{Al}$ in the sample $\mathrm{Cs}(\mu \mathrm{g} / \mathrm{ml})$, and the average blank, $\mathrm{Cb}$ $(\mu \mathrm{g} / \mathrm{ml})$ were obtained from the measurement data. The final solution volumes of samples $\mathrm{Vs}(\mathrm{ml})$ and blank, $\mathrm{Vb}$ $(\mathrm{ml})$ were used. The concentration, $\mathrm{C}(\mu \mathrm{g} / \mathrm{g})$ of each sample in the mass of sample taken, $\mathrm{M}(\mathrm{g})$ was calculated as follows: $\mathrm{C}(\mu \mathrm{g} / \mathrm{g})=(\mathrm{CsVs}-\mathrm{CbVb}) / \mathrm{M}$. Three standard concentrations, $0,0.25$ and $0.5 \mu \mathrm{g}$ of metal stock solution $(1000 \mu \mathrm{g} / \mathrm{ml})$, were added to $1 \mathrm{~g}$ of sample and then digested as described previously to calculate recoveries.

Results are expressed as $\mathrm{mg} / \mathrm{kg}$ of fresh meat. Detection limits are defined as the concentration corresponding to three times the standard deviation of ten blanks. Detection limit value of $\mathrm{Al}$ was $0.10 \mathrm{mg} / \mathrm{kg}$. The percentages of recovery ranged from 93 to $100 \%$.

\section{Statistical Analysis}

Data were calculated as mean \pm standard deviation (SD) analyzed using analysis of variance (ANOVA). Probability of 0.05 or less $(\mathrm{P}<0.05)$ was considered significant. The statistical package of Costat Program (Costat 1986) was used for all chemometric calculations.

\section{RESULTS AND DISCUSSION}

The levels of $\mathrm{Al}$ for raw and red meats cooked under different conditions and wrapped in aluminium foil are given in Table 1. The effects of cooking treatment on $\mathrm{Al}$ contents of red meats were significant $(\mathrm{P}<0.05)$. The contents of $\mathrm{Al}$ in raw muscle beef (Fig.1-A,B) increased from 20.20 to $24.50 \mathrm{mg} / \mathrm{kg}$ at $150{ }^{\circ} \mathrm{C}$ for $60 \mathrm{~min}, 28.67$ $\mathrm{mg} / \mathrm{kg}$ at $200{ }^{\circ} \mathrm{C}$ for $40 \mathrm{~min}$, and $33.60 \mathrm{mg} / \mathrm{kg}$ at $250{ }^{\circ} \mathrm{C}$ for $20 \mathrm{~min}$. In case of liver beef, the levels of $\mathrm{Al}$ were $25.4,32.60,38.70$ and $45.00 \mathrm{mg} / \mathrm{kg}$ for raw, cooking at $150{ }^{\circ} \mathrm{C}$ for $60 \mathrm{~min}, 200{ }^{\circ} \mathrm{C}$ for $40 \mathrm{~min}$ and $250{ }^{\circ} \mathrm{C}$ for $20 \mathrm{~min}$, respectively. Also data in Table 1 illustrate that , Al levels were 16.22, 17.88, 21.50 and $25.88 \mathrm{mg} / \mathrm{kg}$ in muscles of water buffalo and 23.50, 30.42, 35.66, 40.50 $\mathrm{mg} / \mathrm{kg}$ in livers of water buffalo for raw , cooking at 150 ${ }^{\circ} \mathrm{C}$ for $60 \mathrm{~min}, 200{ }^{\circ} \mathrm{C}$ for $40 \mathrm{~min}$ and $250{ }^{\circ} \mathrm{C}$ for 20 min, respectively (Fig.2-A,B).

For muscles of sheep (Fig.3-A,B) , Al levels increased from 10.44 in raw to $13.33,16.25$ and 19.16 $\mathrm{mg} / \mathrm{kg}$ when cooked at $150{ }^{\circ} \mathrm{C}$ for $60 \mathrm{~min}, 200{ }^{\circ} \mathrm{C}$ for $40 \mathrm{~min}$ and $250{ }^{\circ} \mathrm{C}$ for $20 \mathrm{~min}$, respectively. For liver samples, the levels of $\mathrm{Al}$ were found to increase from 15.34 in raw to $19.22,23.33,27.90 \mathrm{mg} / \mathrm{kg}$ when cooked at $150{ }^{\circ} \mathrm{C}$ for $60 \mathrm{~min}, 200{ }^{\circ} \mathrm{C}$ for $40 \mathrm{~min}$ and 250 ${ }^{\circ} \mathrm{C}$ for $20 \mathrm{~min}$, respectively.

Data in Table 2 show that cooking treatments significantly affected the $\mathrm{Al}$ contents of poultry meats (P $<0.05)$. As in the case of red meats, the lowest $\mathrm{Al}$ content was observed in the raw meats and the highest in those cooked at $250{ }^{\circ} \mathrm{C}$ for $20 \mathrm{~min}$. For cooked chicken breast, chicken leg (Fig.4-A,B), turkey breast and turkey leg (Fig.5-A,B) wrapped in aluminium foil, Al contents increased by $12.2,14.8,21.7$ and $24.3 \%$ at 150 ${ }^{\circ} \mathrm{C}$ for $60 \mathrm{~min} ; 32.8,37.5,41.3$ and $43.4 \%$ at $200^{\circ} \mathrm{C}$ for $40 \mathrm{~min}$, and $41.1,59.7,68$ and $75 \%$ at $250{ }^{\circ} \mathrm{C}$ for 20 min, respectively. Therefore, the least increase was traced in the samples cooked at low temperature for a long time $\left(150{ }^{\circ} \mathrm{C}\right.$ for $\left.60 \mathrm{~min}\right)$ while the highest increase was recorded for the samples cooked at a high temperature for a short time $\left(250^{\circ} \mathrm{C}\right.$ for $\left.20 \mathrm{~min}\right)$. These results are in agreement with Turhan (2006) who found that cooking temperature is more important in $\mathrm{Al}$ leaching than cooking time. 

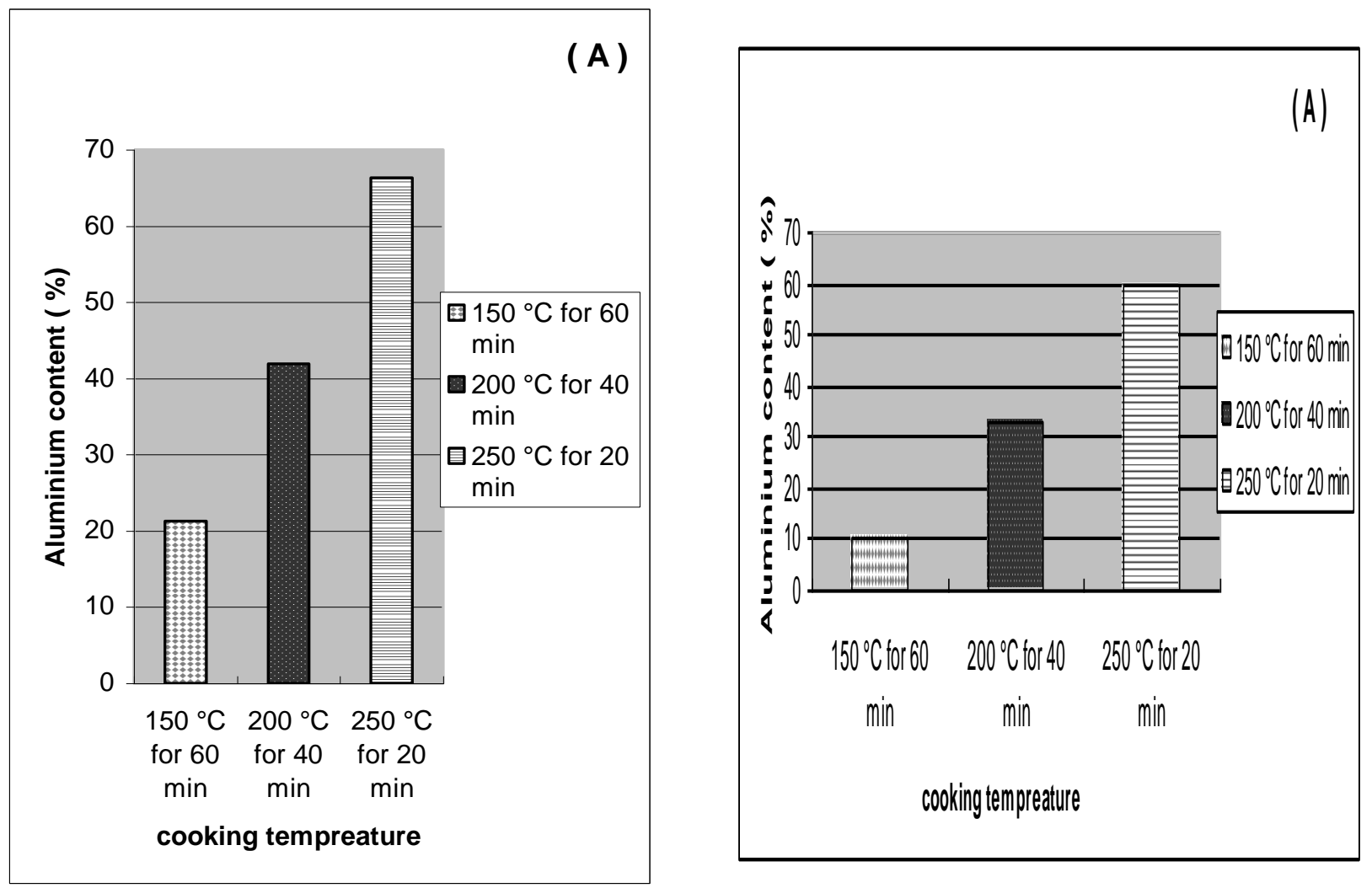

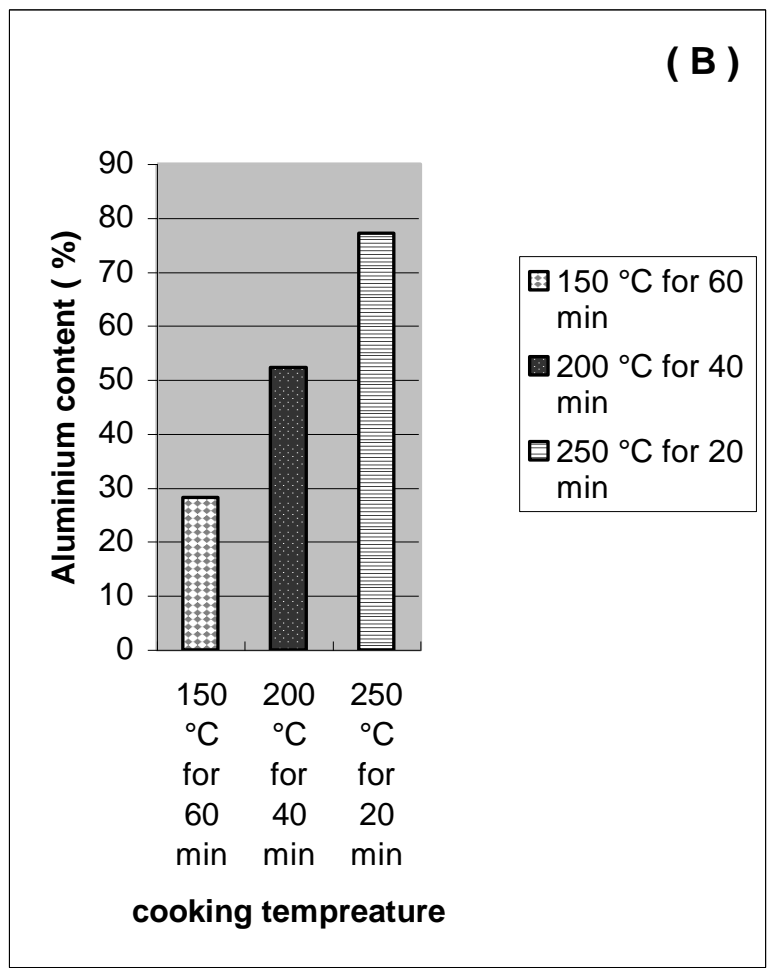

Fig.1.Effect of cooking conditions on Al content of Beeff
(A ): Muscles
( B ): liver

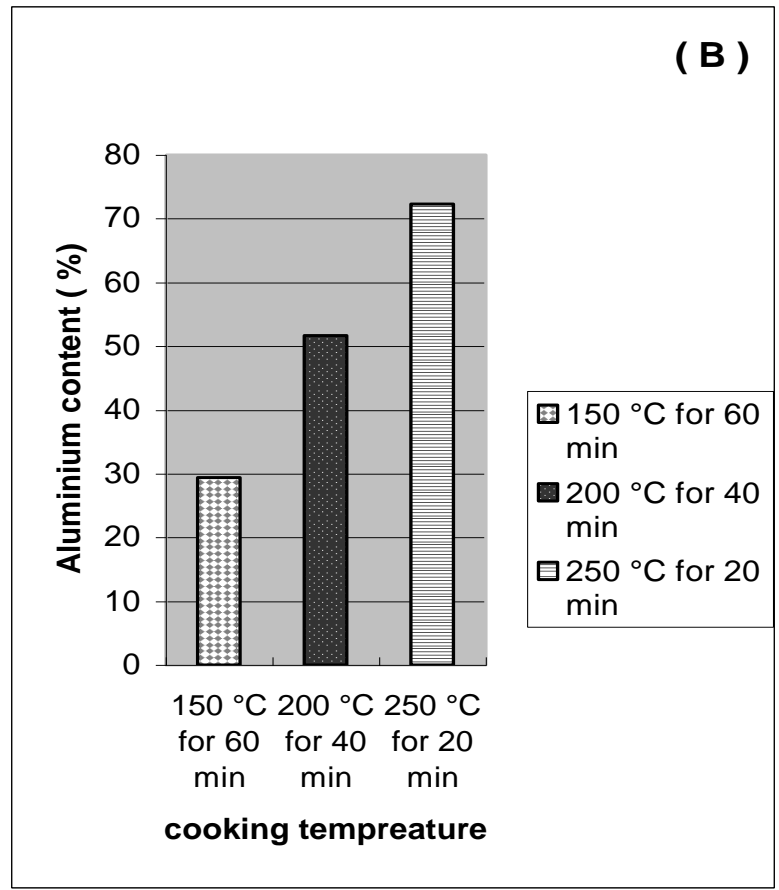

Fig.2. Effect of cooking conditions on Al content of Water buffalo
( A ): Muscles
( B ): liver 

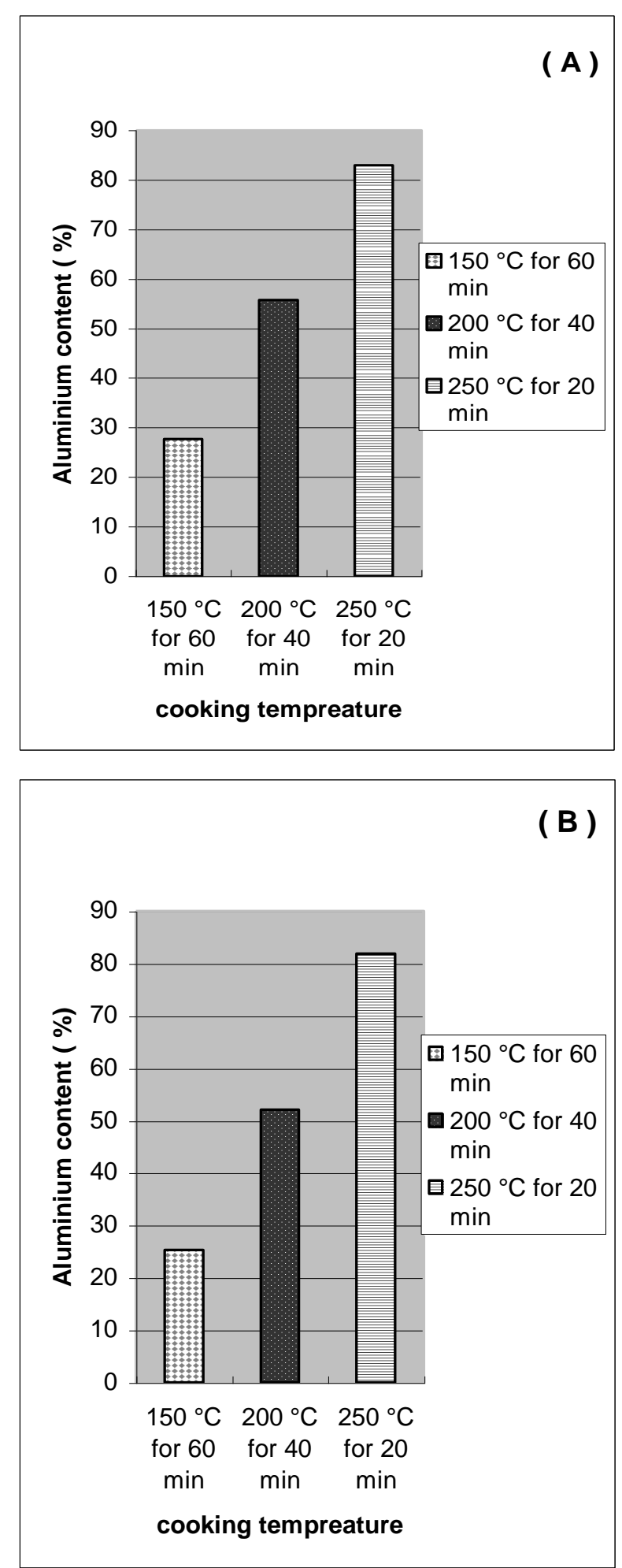

Fig.3. Effect of cooking conditions on Al content of Sheep
(A ): Muscles
( B ): live
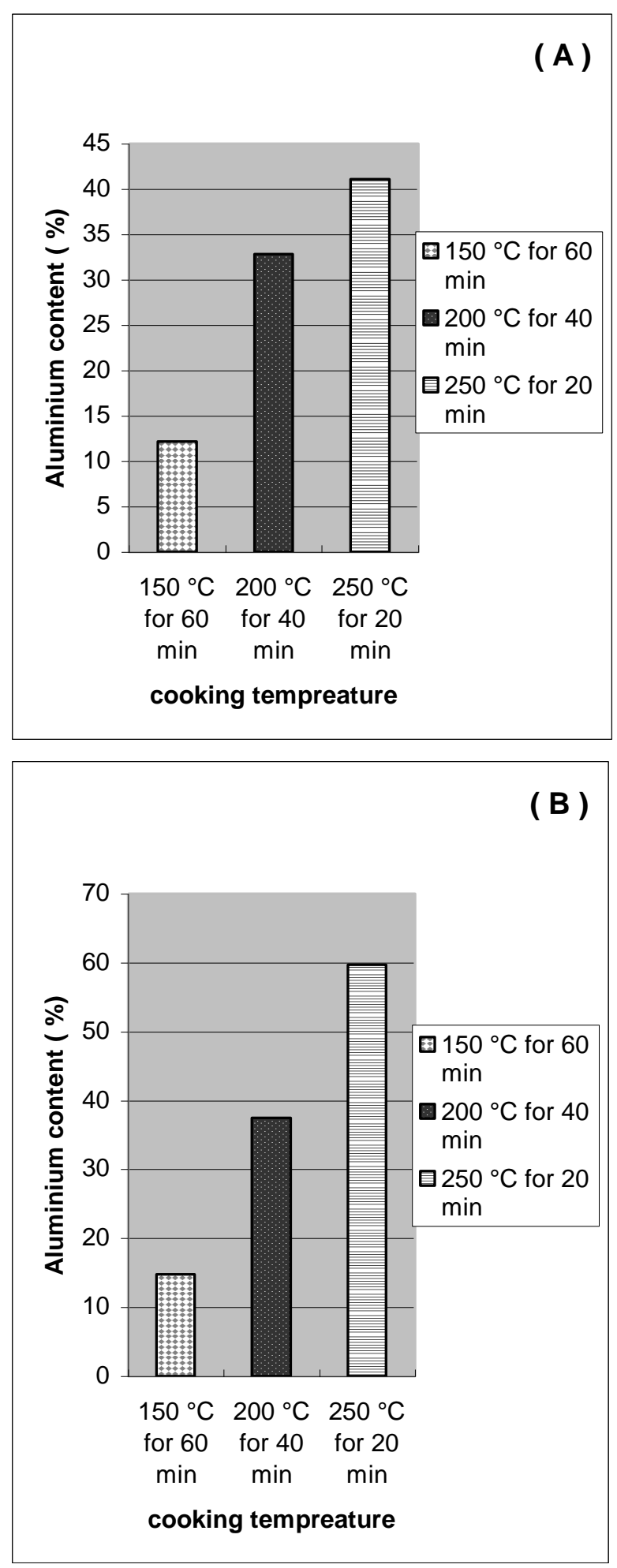

Fig. 4. Effect of cooking conditions on Al content of Chicken
(A ): Breast
(B ): Leg 

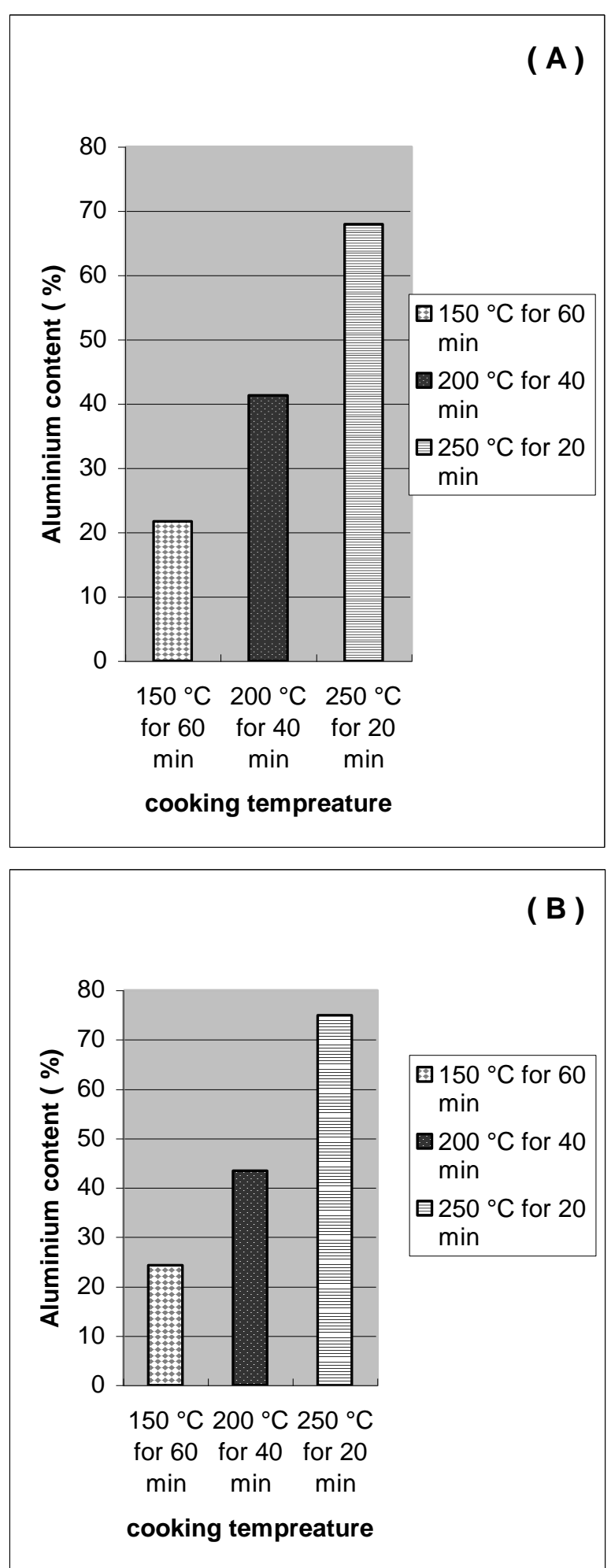

Fig.5. Effect of cooking conditions on Al content of Turky
( A ): Breast
(B ): Leg

This may be explained on the basis that the higher cooking temperature stimulated the leaching of $\mathrm{Al}$ from foil to meats, because at elevated temperatures, the oxide layer becomes thicker and changes from an amorphous to a crystalline structure (Rajwanshi et al., 1997).

Ranau et al. (2001) found that the Al concentration of wrapped and cooked fillets was higher than samples cooked in an oven at $200{ }^{\circ} \mathrm{C}$. In addition, cooking in aluminium utensils increased $\mathrm{Al}$ concentration of foods (Greger et al., 1985; Watanabe and Dawes, 1988; Gramiccioni et al., 1996; Fimreite et al., 1997; Yaman et al., 2003 ; Scancar et al., 2004).Meanwhile, Gramiccioni et al. (1996) found that Al concentration of 'meat cannelloni' prepared in aluminium cookware increased by $25 \%$. Also, greater increase in $\mathrm{Al}$ contents was found in sauerkraut and sour turnip stating that aluminium utensils are not suitable for acidic foods (Scancar et al., 2004)

The increase in $\mathrm{Al}$ concentrations of muscles sheep (27.7\% at $150{ }^{\circ} \mathrm{C}$ for $60 \mathrm{~min}, 55.7 \%$ at $200{ }^{\circ} \mathrm{C}$ for 40 min, and $83 \%$ at $250{ }^{\circ} \mathrm{C}$ for $20 \mathrm{~min}$ ) after cooking were significantly higher than their counterparts in both beef and water buffalo muscles .In contrast, the $\mathrm{Al}$ content increment of liver sheep (81.9\%) was significantly higher than beef $(77.2 \%)$ and water buffalo (59.6\%) cooked at $250^{\circ} \mathrm{C}$ for $20 \mathrm{~min}$. For the red meats, livers had significantly higher Al contents than muscles. Also, the raw beef muscles and livers had significantly higher Al contents than the raw water buffalo and sheep muscles and livers. In case of poultry, the increase in $\mathrm{Al}$ concentrations of breast and leg of turkey was significantly higher than breast and leg of chicken after cooking either at $150{ }^{\circ} \mathrm{C}$ for $60,200{ }^{\circ} \mathrm{C}$ for $40 \mathrm{~min}$ or $250{ }^{\circ} \mathrm{C}$ for $20 \mathrm{~min}$. This variation may be due to the chemical composition of meats (Turhan, 2006).

In addition, raw chicken and turkey- breast meats had higher significantly $\mathrm{Al}$ contents than both raw chicken and turkey leg meats. This finding shows that poultry- breast meats store more $\mathrm{Al}$ than leg meats do.

\section{CONCLUSION}

The present investigation indicated that cooking in aluminium foil increase the $\mathrm{Al}$ content of either red or white meats. It was found that migration of ingredients from active packaging into food stuffs may occurred (Lopez-Cervantes et al., 2003; Osman and AlRehiayani, 2006). This may present a potential threat to health, security and safety of such food items to unsuspecting consumer. .Aluminium contents ranged from 10.44 to $25.40 \mathrm{mg} / \mathrm{kg}$ in raw red meats and 13.33 to $45.00 \mathrm{mg} / \mathrm{kg}$ in cooked red meats, while it ranged from 17.05 to $25.23 \mathrm{mg} / \mathrm{kg}$ in raw poultry meats, and 
21.20 to $35.60 \mathrm{mg} / \mathrm{kg}$ in cooked poultry meats. In all tested samples, the lowest increase in $\mathrm{Al}$ levels was observed in the samples cooked at $150{ }^{\circ} \mathrm{C}$ for $60 \mathrm{~min}$, while the highest levels were found in samples cooked at $250{ }^{\circ} \mathrm{C}$ for $20 \mathrm{~min}$.

Regarding the suggested provisional tolerable daily intake of $1 \mathrm{mg} \mathrm{Al} / \mathrm{kg}$ body weight/day (FAO/WHO, 1994), it can be stated that there is no evident risk to the health of consumer. However, it is possible that excessive consumption of foods wrapped with aluminium foil may carry a health risk because cooking processes affect the migration of aluminium.

Data of the present study can be considered as a guide for resturants, fast food outlets and hotels to avoid wrapping of meats in aluminium foils prior to cooking, and use glass utensils for food cooking instead of aluminium foil in order to prevent contamination of meats with aluminium.Notwithstanding, if there is no way to use aluminium foil in wrapping of meats, it is advisable to apply low cooking temperature for a long period (i.e. $150{ }^{\circ} \mathrm{C}$ for $60 \mathrm{~min}$.). Such a treatment results in a decline the migration rate of $\mathrm{Al}$ from foil to food.

\section{REFERENCES}

Blunden, S. and Wallace, T. (2003). Tin canned food: a review and understanding of occurrence and effect. Food Chem. Toxicol., 41(12): 1651-1662.

Costat 1986. Version 2, Cohort Software. Minneapolis, MN, USA.

FAO/WHO. (1994). Summary evaluations performed by the Joint FAO/WHO Expert Committee on Food Additives (JECFA).

Fimreite, N., Hansen, O. B., \& Pettersen, H. C. (1997). Aluminium concentrations in selected foods prepared in aluminium cookware, and its implications for human health. Bull. Environ. Contam. Toxicol., 58: 1-7.

Gauthier, E.; Fortier, I.; Courchesne, F.; Pepin, P.; Mortimer, J. and Gauvreau, D. (2000). Aluminium forms in drinking water and risk of Alzheimer's disease. Environ. Res., 84: 234-246.

Gramiccioni, L.; Ingrao, G.; Milana, M. R.; Santaroni, P. and Tomassi, G.

(1996). Aluminium levels in Italian diets and selected foods from aluminium utensils. Food Addit. Contam., 13: 767-774.

Grant, W. B.; Campbell, A; Itzhaki, R. F. and Savory, J. (2002). The significance of environmental factors in the etiology of Alzheimer's disease. J. Alzheimer's Disease, 4: 179-189.

Greger, J. L., Goetz, W., \& Sullivan, D. (1985). Aluminium levels in foods cooked and stored in aluminium pans, trays and foil. J. Food Protect., 48: 772-777.

Gupta, V. B.; Suram, A.; Hegde, M. L.; Zecca, L.; Garruto, R. M.; Ravid, R., et al. (2005). Aluminium in Alzheimer's disease: are we still at a crossroads? CMLS Cell. Molec. Life Sci., 62: 1-16.

Joshi, S. P.; Toma, R. B.; Medora, N. and O'Connor, K. (2003). Detection of aluminium residue in sauces packaged in aluminium pouches. Food Chem., 83: 383-386.

Lopez-Cervantes, J.; Sanchez-Machado, D.I.; Pastorelli, S.; Rijk, R. and Paseiro-Losada, P. (2003). Evaluating the migration of ingredients from active packing and development of dedicated methods: a study of two iron-based oxygen absorbers. Food Addit. Contam., 20(3): 291-299.

McWilliams, M. (1989). Foods: Experimentals perspective. New York: Macmillan Publishing Company.

Meiri, H.; Banin, E.; Roll, M. and Rousseau, A. (1993). Toxic effects of aluminium on nerve cells and synaptic transmission. Progress in Neurobiol., 40: 89-121.

Miu, A. C.; Olteanu, A. I. and Miclea, M. (2004). A behavioral and ultrastructural dissection of the interference of aluminium with aging. $\mathrm{J}$. Alzheimer's Disease, 6: 315-328.

NIOSH (1994). Manual of Analytical Methods. National Institute for Occupational Safety and Health, (4th Edition)., P.M. Eller and M.E. Cassinelli (Editors.), Cincinnati, Ohio, 8/15/94.

Osman, K.A. and Al-Rehiayani, S. (2006). Monitoring of selected metals in canned foods. Agric. Marine ASci., Sultan Qaboos Univ., Sultante of Oman, 11(1): 7-15.

Polizzi, S.; Pira, E.; Ferrara, M.; Bugiani, M.; Papaleo, A.; Albera, R., et al. (2002). Neurotoxic effects of aluminium among foundry workers and Alzheimer's disease. Neurotoxicol., 23: 761-774.

Rajwanshi, P.; Singh, V.; Gupta, M. K. and Dass, S. (1997). Leaching of aluminium from cookwares - a review. Environ. Geochem. Health, 19: 1-18.

Rajwanshi, P.; Singh, V.; Gupta, M. K.; Shrivastav, R.; Subramanian, V.; Prakash, S.; et al. (1999).Aluminium leaching from surrogate aluminium food containers under different $\mathrm{pH}$ and fluoride concentration. Bull. Environ. Contam Toxicol., 63: 271-276.

Ranau, R.; Oehlenschlager, J. and Steinhart, H. (2001). Aluminium levels of fish fillets baked and grilled in aluminium foil. Food Chem., 73: 1-6. 
Rondeau, V.; Commenges, D.; Jacqmin-Gadda, H. and Dartigues, J. F.(2000). Relation between aluminium concentrations in drinking water and Alzheimer's disease: an 8-year follow-up study. Amer. J. Epidemiol, 152: 59-66.

Scancar, J.; Stibilj, V. and Milacic, R. (2004). Determination of aluminium in Slovenian foodstuffs and its leachability from aluminium-cookware. Food Chem., 85: 151-157.

Turhan, S. (2006). Aluminium contents in baked meats wrapped in aluminium foil. Meat Sci. 74, 644-647.
Watanabe, S. and Dawes, C. (1988). The effect of $\mathrm{pH}$ and fluoride on leaching of aluminium from kitchen utensils. Fluoride, 21: 58-59.

World Health Organization (WHO) (1982). Evaluation of Certain Food Additives and Contaminants, World Health Organization, Geneva.

Yaman, M.; Gunes, M. and Bakirdere, S. (2003). Contamination of aluminium from cooking utensils and yogurt containers. Bull. Environ. Contam. Toxicol., 70: 437-442. 


\section{الملخص العربي}

تأثير عمليات الطهي على انتقال معدن الألمونيوم للحوم المغلفة برقائق الألمونيوم تحت ظروف الطهي بالمطاعم

خالد أحمد عثمان و هالة حسن السيد

كما أوضحت النتائج أن أقل زيادة في محتوي اللحوم من عنصر

الألمونيوم كانت للحوم التي تم طهيهاعلى درجة حرارة 150 م م و لمدة

60 دقيقة، بينما تبين أن أعلى تركيز كان موجودا في اللحوم التي تم

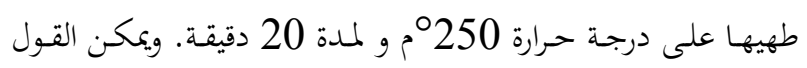

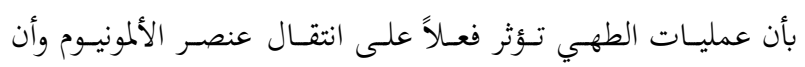

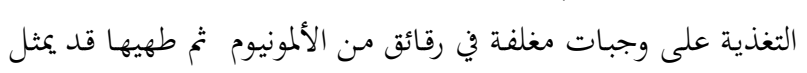

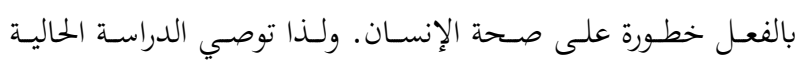

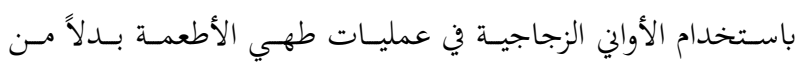

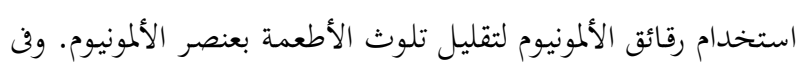

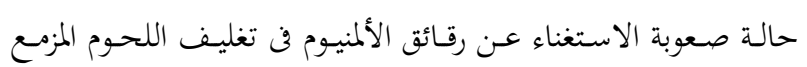

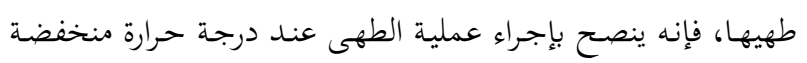

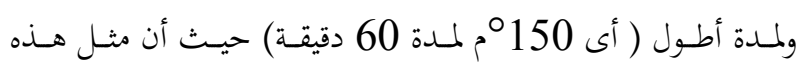
المعاملة تؤدى إلى خفض معدل انتقال الألمونيوم من رقائقه إلى الغذاء المغلف بها، وهو ما أوضحته هذه الدراسة.
يعتبر طهى اللحوم بعد تغليفها برقائق الألمنيوم من الممارسات

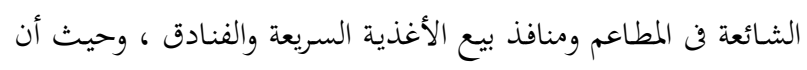

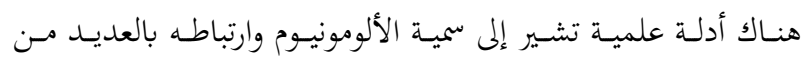

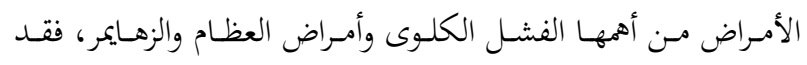

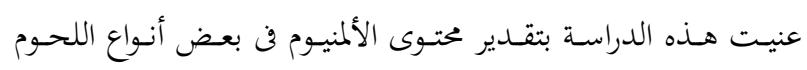
حيث تم دراسة تأثير بعض عمليات الطهي المستخدمة في المطاعم

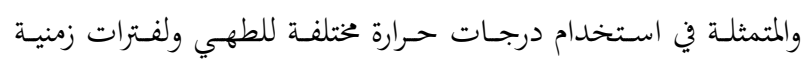

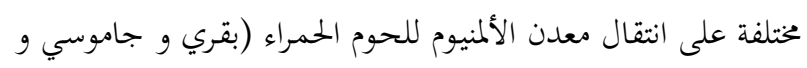
غنم) و للحوم البيضاء (دجاج و رومي) تم تغليفها في رقائق الألمنيوم، النماء

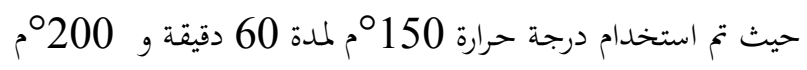

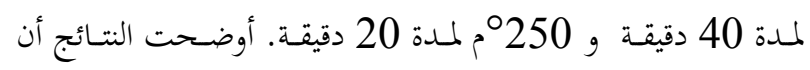
جميع ظروف عمليـات الطهي المختـبرة قـد أدت إلى زيادة معنويـة في

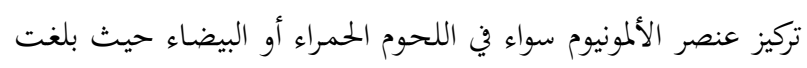

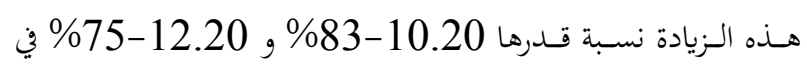
اللحوم الحمراء و البيضاء، على التوالي. 